\title{
gem-Difluorovinyl Derivatives as Insecticides and Acaricides
}

\author{
Thomas Pitterna*, Manfred Böger, and Peter Maienfisch
}

\begin{abstract}
The insecticidal lead 1,1-difluorododec-1-ene was optimised. This compound has attractive insecticidal activity against tobacco budworm (Heliothis virescens), banded cucumber beetle (Diabrotica balteata), pea aphid (Aphis cracciovora), brown planthopper (Nilaparvata lugens), and green rice leafhopper (Nephotettix cincticeps). Among different pharmacophore analogues, only 1,1-dichlorododec-1-ene and 1,1-difluoro-2-iodododec-1-ene showed weak insecticidal activity, whereas similar compounds such as 1-chloro-1-fluorododec-1-ene, 1-fluorododec-1-ene, and 1,1-difluoro-2-bromododec-1-ene were inactive. Only bridge analogues with even-numbered carbon chains were active, for example 1,1-difluorodec-1-ene and 1,1-difluorotetradec-1-ene. Odd-numbered analogues such as 1,1-difluoronon-1-ene, 1,1-difluoroundec-1-ene, 1,1-difluorotridec-1-ene, and 1,1-difluoro-pentadec-1-ene showed no activity. Modification of the tail group led to the analogues 12,12-difluorododec-11-enoic acid and its methyl ester, 12,12-difluorododec-11-en-1-ol, 1,1-difluoro-12-methoxydodec-1-ene, and 12,12-difluorododec-11-enylamine, all of which showed insecticidal activity. 12,12-difluorododec-11-enoic acid methyl ester, 12,12-difluorododec-11-enoic acid, and 12,12-difluorododec-11-en-1-ol were also active against spider mites (Tetranychus ssp). Thus, in a first optimisation cycle, broad activity against insect pests and mites was discovered. Two requirements, the gem-difluorovinyl pharmacophore and an even-numbered carbon chain, were found to be essential for activity. This latter requirement is in line with the proposed mode of action, which involves inhibition of the $\beta$-oxidation of fatty acids in insect mitochondria. In a second optimisation cycle, it was found that 6,6-difluorohex-5-enoic acid and its derivatives, such as acids, amides, and hydrazides, possess even superior properties as insecticides and acaricides. This led to the discovery of 6,6-difluorohex-5-enoic acid 2-[4-(4-trifluoromethylbenzyloxy)-phenoxy]-ethyl ester (CGA 304'111). This compound showed excellent performance in field trials against a wide range of pests, as well as a more favourable toxicological profile than earlier derivatives. For a largescale synthesis of CGA 304'111, five different synthetic routes for 6,6-difluorohex-5-enoic acid were developed. The best route involved radical addition of $\mathrm{CBrClF}_{2}$ to pent-4-enoic acid. Removal of bromine by hydrogenation, elimination of chloride and hydrolysis of the ester concluded this most efficient sequence. Thus, a practical synthesis for CGA 304'111 was identified, which allowed the preparation of samples on a several $100 \mathrm{~g}$ scale.
\end{abstract}

Keywords: Acaricide · CGA 304'111 · 6,6-Difluorohex-5-enoic acid · gem-Difluorovinyl · Insecticide

\section{Introduction}

As part of our activities in patent monitoring [1], 1,1-difluorododec-1-ene (1) has been prepared. In our insecticide screening this compound showed attractive insecticidal activity against tobacco budworm $(\mathrm{He}$ -
${ }^{*}$ Correspondence: Dr. T. Pitterna Syngenta Crop Protection AG, $\mathrm{CH}-4002$ Basel

Tel.: +4161323 8488

Fax: +4161323 8529

E-Mail: thomas.pitterna@syngenta.com liothis virescens), banded cucumber beetle (Diabrotica balteata), pea aphid (Aphis cracciovora), brown planthopper (Nilaparvata lugens) and green rice leafhopper (Nephotettix cincticeps). At the same time, we learned from studies by Ruder [2], that the most important commercially established insecticidal modes of action could be excluded. Because of the broad activity spectrum against key pests and the potentially new mode of action, an optimisation project was started.

Lead structure 1 can be dissected in pharmacophore, bridge and tail (Fig. 1). In a first optimisation cycle each of these structural elements was optimised separately. This approach yielded compounds with insecticidal and, in addition, acaricidal activity. Further optimisation led to the discovery of CGA 304'111, a compound with improved properties. Because of the need to provide larger samples for field trials, a practical synthesis of CGA 304'111 was developed.

In this account, we describe the synthesis of the compounds that were relevant for our optimisation program, as well as their pesticidal activities. We also present different synthetic routes for 6,6-difluorohex-5enoic acid (35), which is an important building block for CGA 304'111 (37).

\section{1st Optimisation Cycle}

Lead structure 1 was obtained from aldehyde 3 by a fluoroylide reaction, $(E)-1$ fluorododec-1-ene (9) by reduction of $\mathbf{1}$ with Redal ${ }^{\circledR}$. Both reactions have been described by Hayashi et al. [3]. 1,1-Difluorododecane (4) was prepared from aldehyde 2 by fluorination with DAST, as de- 


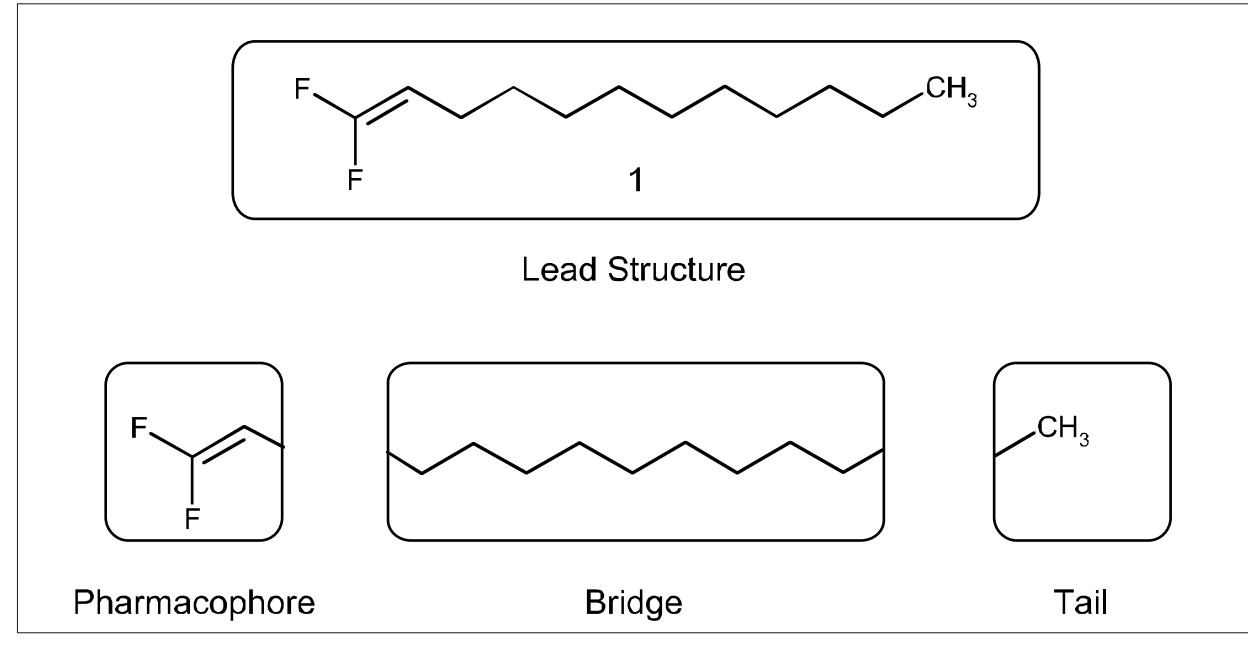

Fig. 1. First optimisation cycle. Structural elements of lead compound 1.

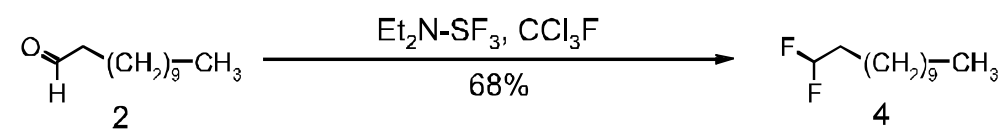

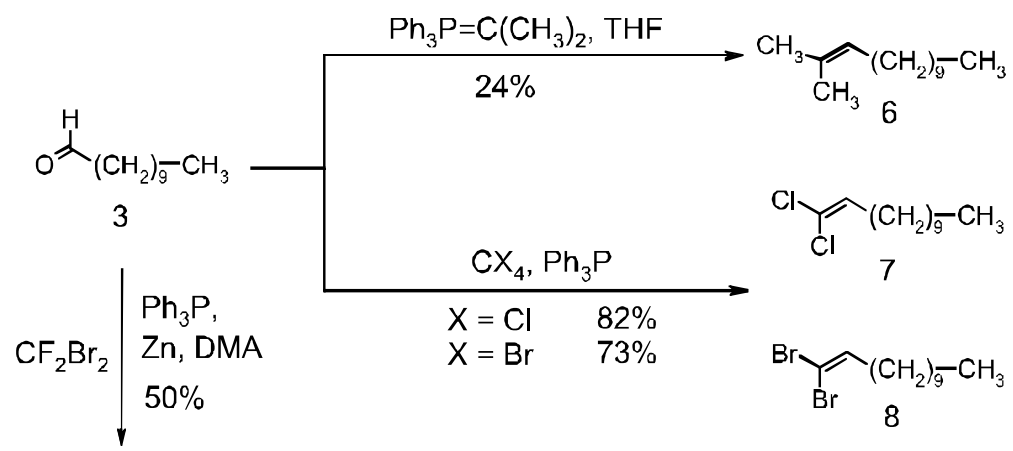

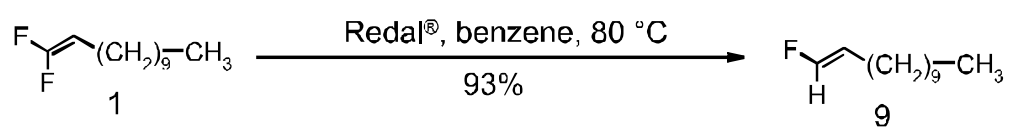

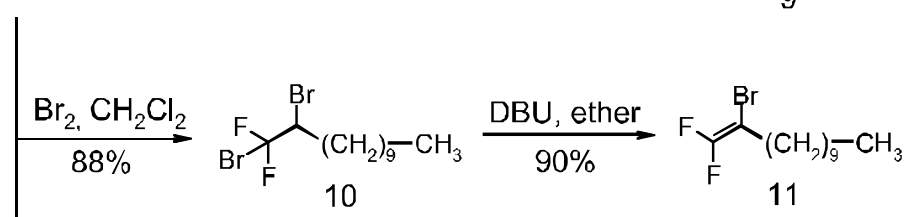

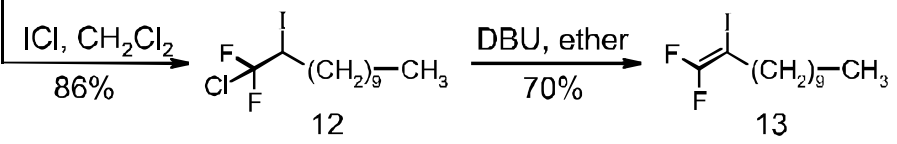<smiles>CCCCCC</smiles>

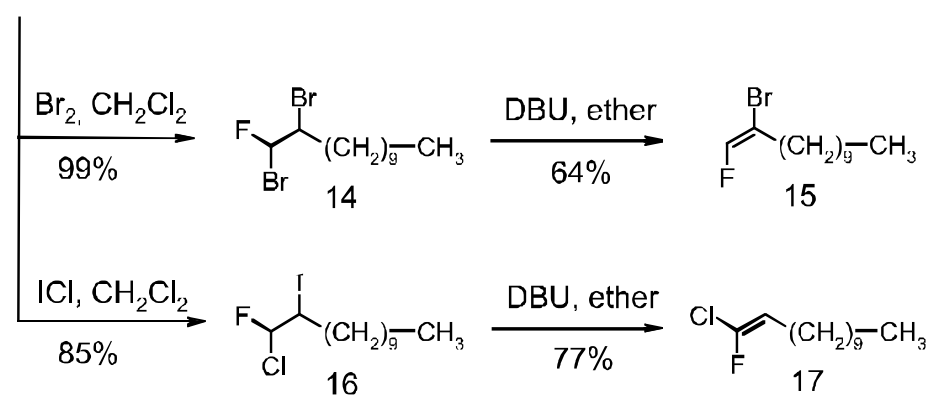

scribed by Middleton [4]. 2-Methyltridec2-ene (6) was obtained from aldehyde $\mathbf{3}$ by Wittig reaction with instant ylide, as described by Schlosser and Schaub [5]. The dihalovinyl-compounds $\mathbf{7}$ and $\mathbf{8}$ were also prepared from aldehyde $\mathbf{3}$ by reaction with triphenylphosphine and perhalomethanes, as described by Appel and coworkers [6] and Corey and Fuchs [7] (Scheme 1). The addition of bromine to the double bond of $\mathbf{1}$, as described by Suda [8], gave 10, which upon treatment with DBU eliminated bromide to give 11. Related elimination reactions have been previously described by Burton et al. and by Brahms and Dailey [9], but only for substrates activated by a phenyl- or a carboxyl group, yielding 1,1difluorostyrenes or 3,3-difluoroacrylic acid, respectively.

We have found that difluoroolefin $\mathbf{1}$ adds iodinemonochloride in a regioselective manner resulting in 1-chloro-1,1-difluoro-2-iodododecane (12), revealing the nucleophilic character of $\mathrm{C}(2)$ of difluoroolefin 1. Although the fluorine substituents diminish the reactivity of the double bond towards electrophiles, they direct the addition of electrophiles by stabilisation of a positive charge at $\mathrm{C}(1)$. This is known from the work of Knunyants and Polishchuck, and Krespan and Petrov [10]. Treatment of $\mathbf{1 2}$ with DBU causes the elimination of chloride (rather than iodide) and of $\mathrm{H}-\mathrm{C}(2)$ to form 1,1-difluoro-2-iodododec-1-ene (13). As $\mathrm{H}-\mathrm{C}(2)$ is the most acidic proton, this outcome of the reaction was expected, still it is unprecedented to the best of our knowledge. The closest analogy described in the literature is the elimination of hydrogen chloride from $\mathrm{Cl}_{-} \mathrm{CF}_{2}-\mathrm{CFI}-\mathrm{H}$ reported by Kendall and Lemal [11], where only one $\beta$-elimination process is possible.

In a similar manner, $(E)$-1-fluorododec1-ene (9) added bromine to give $\mathbf{1 4}$, and iodinemonochloride to give $\mathbf{1 6}$. The two addition products displayed different reactivity upon treatment with DBU, however. From 1,2-dibromo-1-fluorododecane (14) $\mathrm{Br}-\mathrm{C}(1)$ and $\mathrm{H}-\mathrm{C}(2)$ are eliminated, leading to (E)-2-bromo-1-fluorododec-1-ene (15). This is the same direction of elimination as in the reaction of $\mathbf{1 0}$ to $\mathbf{1 1}$, and of $\mathbf{1 2}$ to $\mathbf{1 3}$. In contrast, 1-chloro-1-fluoro-2iodododecane (16) eliminated $\mathrm{H}-\mathrm{C}(1)$ and I-C(2), resulting in the formation of $(E)$-1-chloro-1-fluorododec-1-ene (17).

Both two-step addition/elimination sequences leading from 9 to $\mathbf{1 5}$ and from $\mathbf{9}$ to 17 , respectively, appear to be highly selective (Scheme 2). The observed products are consistent with trans-addition to the double bond, followed by an antiperiplanar arrangement for elimination. To the best of our knowledge, there is no precedence in the literature for the elimination reactions of 14 to 15 and of 16 to 17 , which would 


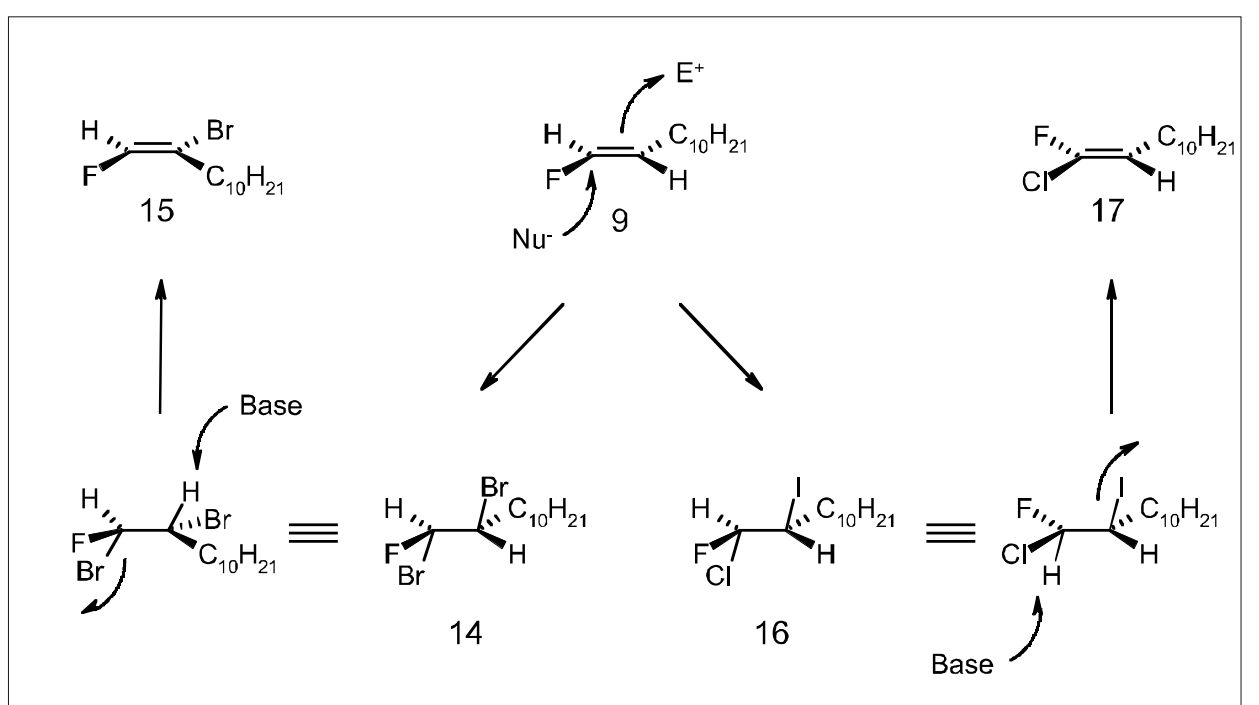

Insecticidal Activity:<smiles>[R]C=C(F)F</smiles><smiles>[R]C(C)=C(F)F</smiles><smiles>[R]C=C(Cl)Cl</smiles>

Inactive:<smiles>[R]CC(F)F</smiles>

11<smiles>[R]C=C</smiles><smiles>[R]C=C(C)C</smiles><smiles>[R]C(C)C(F)(F)Cl</smiles>

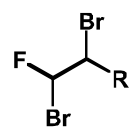

14<smiles>[R]C(Br)=[Bi]Br</smiles><smiles>[R]/C=C\F</smiles><smiles>[R]C(Br)C(F)(F)Br</smiles><smiles>[R]/C(Br)=C/F</smiles>

15

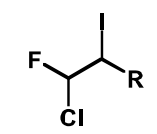

16

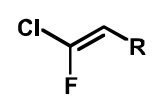

17
Table 1. Activity of compounds with modified pharmacophore against insect pests

\begin{tabular}{|c|c|c|c|c|c|c|}
\hline & compound & H.v. ${ }^{a}$ & D.b. ${ }^{b}$ & A.c. ${ }^{c}$ & N.I. ${ }^{d}$ & N.I. sys ${ }^{e}$ \\
\hline 1 & $\left(\mathrm{CH}_{2}\right)_{9}-\mathrm{CH}_{3}$ & 12.5 & 12.5 & 400 & 400 & 0.75 \\
\hline 7 & $\left(\mathrm{CH}_{2}\right)_{9}-\mathrm{CH}_{3}$ & 400 & $>400$ & $>400$ & 400 & $>12.5$ \\
\hline 9 & $\left.\mathrm{CH}_{2}\right)_{9}-\mathrm{CH}_{3}$ & $>400$ & $>400$ & $>400$ & $>400$ & $>12.5$ \\
\hline 11 & $\left.\mathrm{H}_{2}\right)_{9}-\mathrm{CH}_{3}$ & $>400$ & $>400$ & $>400$ & $>400$ & $>12.5$ \\
\hline 13 & $\left(\mathrm{CH}_{2}\right)_{9}-\mathrm{CH}_{3}$ & 100 & 200 & $>400$ & 400 & 3 \\
\hline 17 & $\left.\mathrm{H}_{2}\right)_{9}-\mathrm{CH}_{3}$ & $>400$ & $>400$ & $>400$ & $>400$ & $>12.5$ \\
\hline
\end{tabular}

have allowed the prediction of the different directions of elimination.

Thus, a representative selection of compounds with different pharmacophores has been prepared (Fig. 2), and screened against tobacco budworm (Heliothis virescens), banded cucumber beetle (Diabrotica balteata), pea aphid (Aphis cracciovora) and brown planthopper (Nilaparvata lugens). Detailed results from the insecticide screening are listed in Table 1. In addition to the gem-difluorovinyl fragment of lead $\mathbf{1}$, only the 1,1-difluoro-2iodovinyl group of $\mathbf{1 3}$ and the gemdichlorovinyl group of $\mathbf{7}$ caused insecticidal activity, albeit clearly weaker than 1 (Fig. 2).

Next, the difluorovinyl pharmacophore was kept constant, and various bridges were introduced, in particular linear alkylene groups, branched and unsaturated groups, as depicted in Scheme 3. The compounds were synthesised in one step from the corresponding aldehydes, again using the protocol from Hayashi et al. [3]. Yields were not optimised.

In Table 2 the results from insecticide screening against tobacco budworm (Heliothis virescens) are shown. It can be ob- 
<smiles>[R]C=O</smiles><smiles>C[Te][Te]</smiles>

$\mathrm{n}=6$

$\mathrm{n}=7$

$\mathrm{n}=8$

18

19

$(6 \%)$

$(28 \%)$

$\mathrm{n}=10$

20

$(22 \%)$

$\mathrm{n}=11$

$(44 \%)$

$\mathrm{n}=12$

22

$(56 \%)$
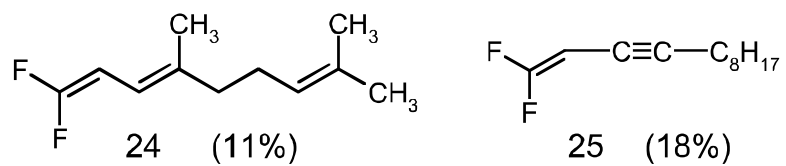

Scheme 3. Synthesis of bridge modifications

Table 2. Heliothis virescens ovolarvicidal activity of compounds with modified bridge

$$
\text { compound }
$$

18<smiles>CCCCCCCC=C(F)F</smiles>

19<smiles>CCCCCCCCC=C(F)F</smiles><smiles>CCCCCCCCCC=C(F)F</smiles>

1<smiles>CCCCCCCCCCC=C(F)F</smiles>

21<smiles>CCCCCCCCCCCC=C(F)F</smiles>

22<smiles>CCCCCCCCCCCCC=C(F)F</smiles>

23<smiles>CCCCCCCCCCCCCC=C(F)F</smiles>

24<smiles>CC(C)=CCC/C(C)=C/C=C(F)F</smiles>

25<smiles>[18O]=CC#CC=C(F)F</smiles>

served that only saturated, linear and unbranched bridges with an even number of carbon atoms possess insecticidal activity (i.e. 1, 19 and 22). Compounds with odd numbers of carbon atoms $(\mathbf{1 8}, \mathbf{2 0}, 21$ and 23) and unsaturated or branched bridges (24 and 25) are devoid of insecticidal activity. On this basis it can be speculated that the mode of action should involve the inhibition of oxidative metabolism of fatty acids to acetyl-CoA. It was confirmed later by independent work of Ruder [2] and Baumert et al. [12], that gem-difluorovinyl carboxylic acids act as inhibitors of $\beta$-oxidation.

Subsequently, we turned our attention to the tail group of lead structure 1. Common intermediate for all other tail group modifications was the methyl ester 27 (Scheme 4), which is accessible from methyl 13-oxoundecanoate (26) by a fluoroylide reaction (Hayashi et al. [3]). Carboxylic acid 28 was prepared from 27 by saponification. Reduction of $\mathbf{2 7}$ gave alcohol 29, from which ether $\mathbf{3 0}$ was obtained by methylation. Amine 32 was prepared by reaction of ammonia with bromide $\mathbf{3 1}$, which was obtained from the alcohol 29 by treatment with triphenylphosphine and bromine.

Table 3 shows results from biological screening of tail group modified derivatives against tobacco budworm (Heliothis virescens), brown planthopper (Nilaparvata lugens) and spider mites (Tetranychus $s s p)$. At this point we were pleased to observe, that the ester $\mathbf{2 7}$, the acid $\mathbf{2 8}$, and the alcohol 29 not only displayed enhanced insecticidal activity as compared to lead compound $\mathbf{1}$, in addition they showed good potency against spider mites.

From our first optimisation cycle we could draw a number of important conclusions. Clearly, the gem-difluoroolefin pharmacophore is needed for activity. A further requirement is an even-numbered carbon chain, which is not branched and contains no additional unsaturation. This appears consistent with the assumption that the compounds interfere with, or are subject to, $\beta$-oxidation (Fig. 3). It is reasonable to assume that all even-numbered gem-difluoroolefins could be oxidised in vivo to gemdifluorovinyl carboxylic acids or derivatives thereof. Perhaps they could be degraded by $\beta$-oxidation to a common active metabolite, the structure of which remains to be investigated. This metabolite could subsequently inhibit one or more of the enzymes of the $\beta$-oxidation cycle. Such a mode of action could be facilitated if the active ingredient is offered already with the required oxidation state at the tail position. While we have no rigorous proof for this hypothesis, we have shown that alcohol-, carboxylic acid- and ester-tails show improved insecticidal activity and, in addition, activity against spidermites. 


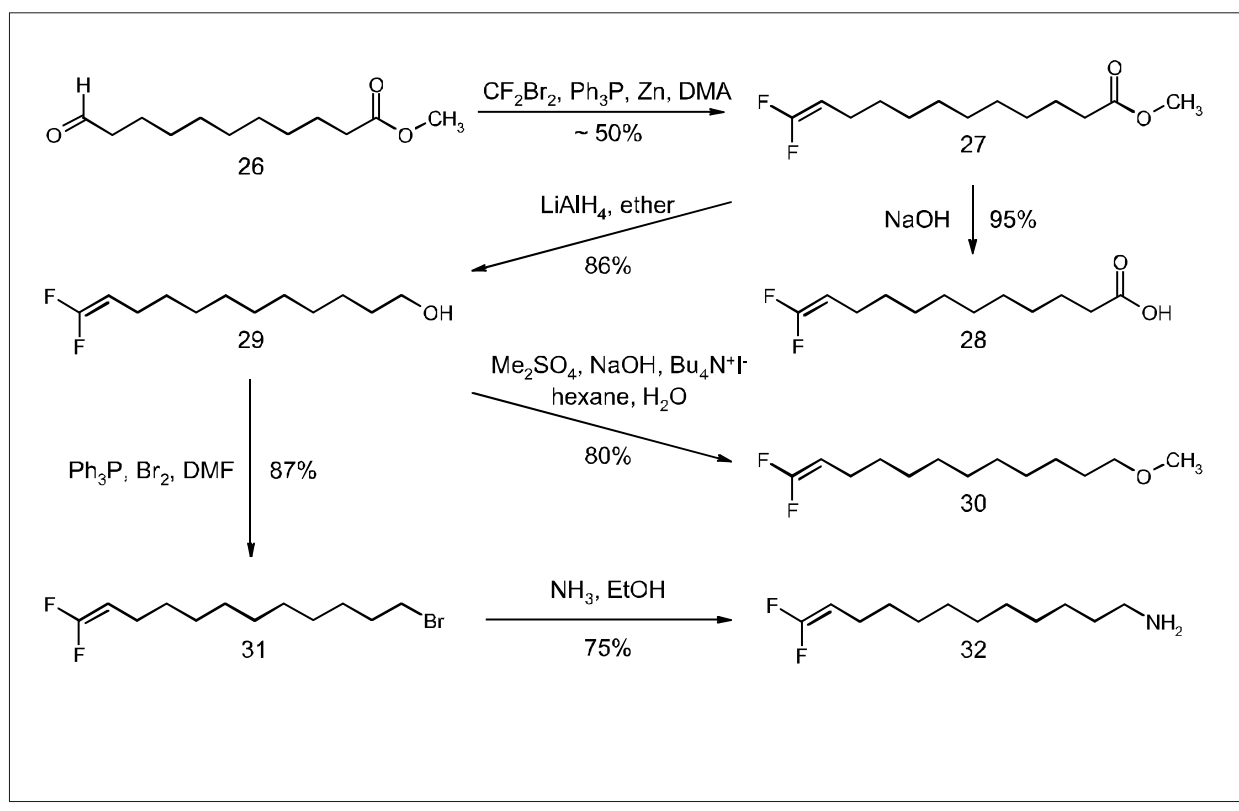

Scheme 4. Synthesis of modified tail structures

Table 3. Activity of compounds with modified tail structures against insects and mites

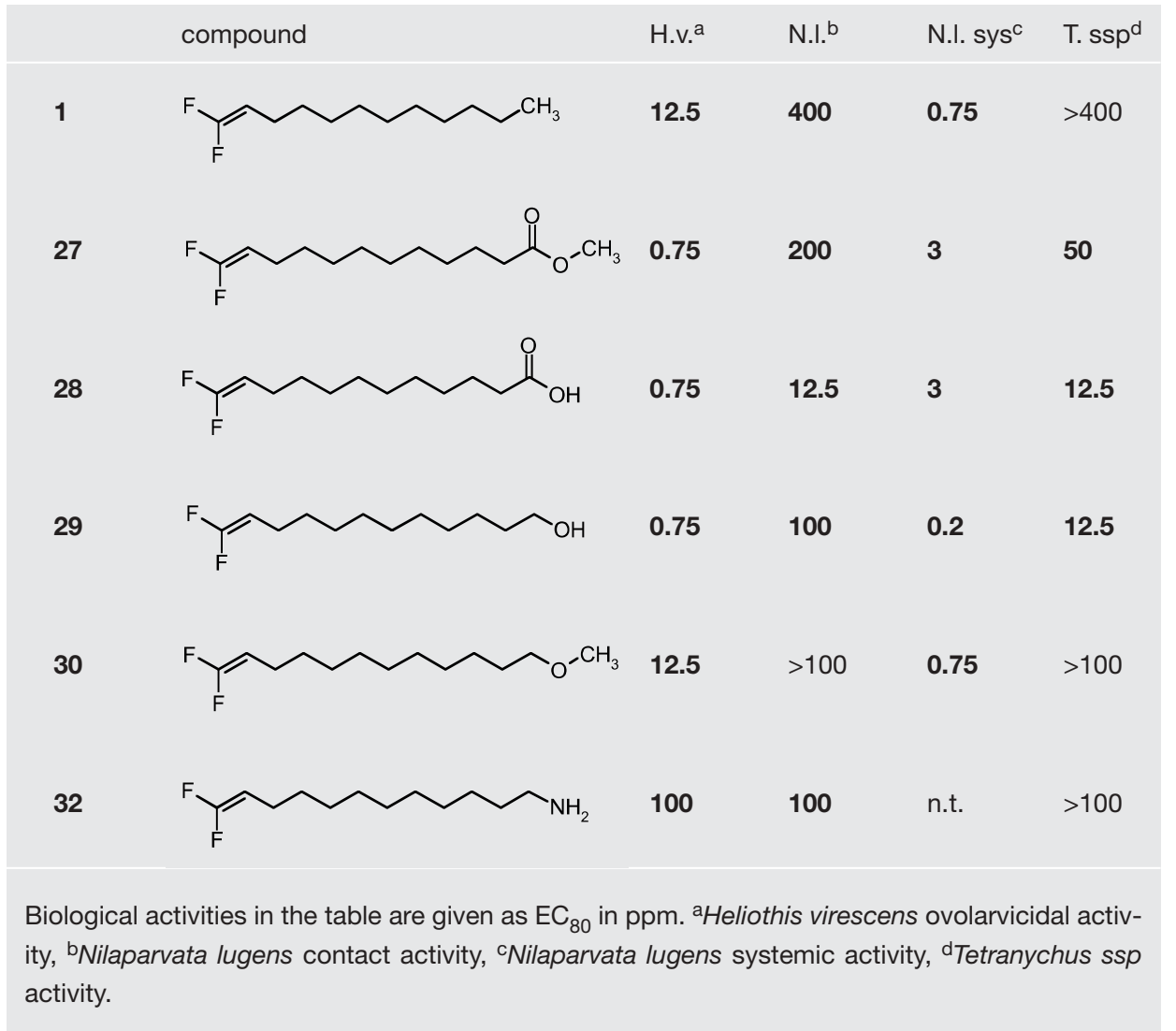

\section{2nd Optimisation Cycle}

Starting point for further optimisation was the carboxylic acid $\mathbf{2 8}$. Beside the encouraging improvement of pesticidal activity, this compound displayed some unwanted properties, such as too high volatility, stench and high acute toxicity in the rat. In order to improve these properties, we investigated various different types of derivatives of acid against brown planthopper (Nilaparvata lugens) and european red mite (Panonychus ulmi). The acute toxicity in the rat is also listed in Table 4. The combination of ester[13] and amide-tails [14] with a propylenebridge gave compounds that showed not only excellent activity against insects and spider mites but also moderate toxicity in the rat. Ester 37, from here on referred to as CGA 304'111, showed the optimal combination of properties.

CGA 304'111 (37) as an acaricide is active against all important mite species in deciduous fruit, citrus, vegetables, tea and cotton. It is equally effective against susceptible and resistant mites. In addition, it is an insecticide against aphids, scales, thrips and jassids. CGA 304'111 can be used as foliar spray, with typical use rates of 10-20 $\mathrm{g} / \mathrm{hl}$, or $150-300 \mathrm{~g} / \mathrm{ha}$. It shows both feeding and contact activity, as well as ovicidal effects. CGA 304'111 has a new mode of action; it interferes with the $\beta$-oxidation of fatty acids. It has a favourable toxicological profile, and would be classified as moderately hazardous (WHO class II).

The synthesis of CGA 304'111 (37) (Scheme 5) involved the coupling of 6,6-difluoro-hex-5-enoyl chloride (42) and alcohol 43. 4-Hydroxy-phenyl-acetophenone (38) was alkylated with 1,3-dioxolan-2-one $\left(170{ }^{\circ} \mathrm{C}\right.$, neat). The resulting 4-(2-hydroxyethoxy)-phenyl-acetophenone (39) was subjected to Bayer-Villiger oxidation and subsequently hydrolysed to give 4-(2-hydroxy-ethoxy)-phenol (40). Alkylation of this phenol with 1-bromomethyl-4-trifluoromethyl-benzene (41) gave alcohol 43. All steps in this sequence proceeded with high to excellent yield. A more challenging endeavour was the synthesis of 6,6-difluorohex-5-enoic acid (35), the precursor of $\mathbf{4 2}$. Acid chloride $\mathbf{4 2}$ was obtained from acid $\mathbf{3 5}$ by reaction with $\mathrm{SOCl}_{2}$. Different synthetic methods for the preparation of $\mathbf{3 5}$ are discussed in the following section.

\section{Synthesis of 6,6-difluorohex-5- enoic acid (35)}

Our first access to this compound relied on difluoroylide chemistry, as shown in Scheme 6. This route worked quite efficiently on a few gram scale. However, for the preparation of larger amounts, as needed for field trials, it was not useful. 1,5-Pentanediol (44) was treated with benzoyl chloride to give the mono-benzoate $\mathbf{4 5}$. Oxidation to the aldehyde $\mathbf{4 6}$, followed by treatment with $\mathrm{CF}_{2} \mathrm{Br}_{2}$ and $\mathrm{P}\left[\mathrm{N}\left(\mathrm{CH}_{3}\right)_{2}\right]_{3}$ according to the procedure of Hayashi et al. [3] gave the gem-difluorovinyl compound 47 in useful yield. However, upon scale-up the yield of this step decreased drastically. Hydrolysis of ester $\mathbf{4 7}$ gave the alcohol $\mathbf{4 8}$, which upon Jones oxidation gave acid $\mathbf{3 5}$. 


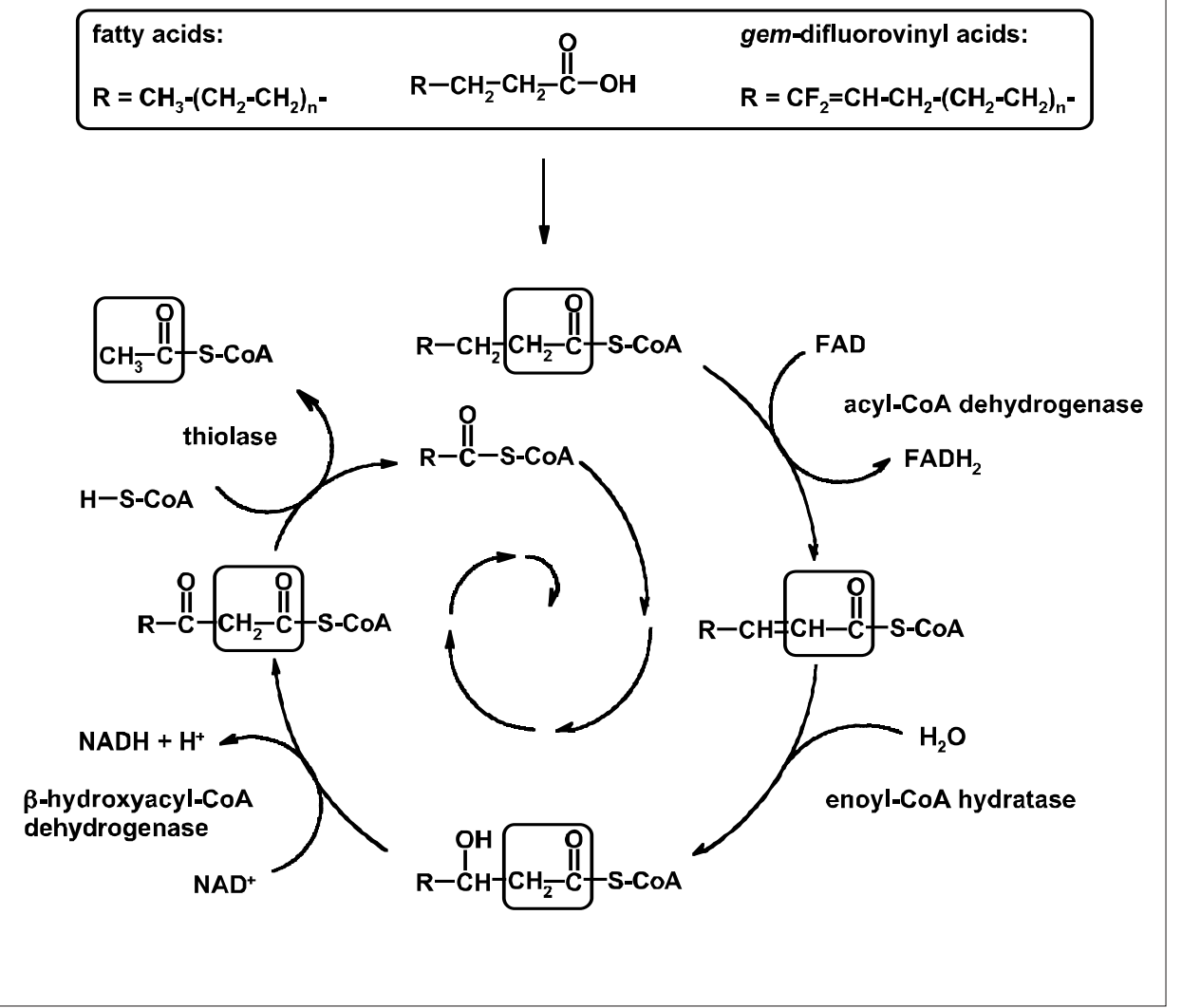

Fig. 3. Mode of action hypothesis. gem-Difluorovinyl derivatives inhibit the fatty acid metabolism in insect mitochondria. gem-Difluorovinyl acids may enter the $\beta$-oxidation cycle as CoA derivatives. This could lead to a common degradation product from different even numbered gemdifluorovinyl analogues. Such a product may inhibit one or more of the enzymes that are involved in $\beta$-oxidation.
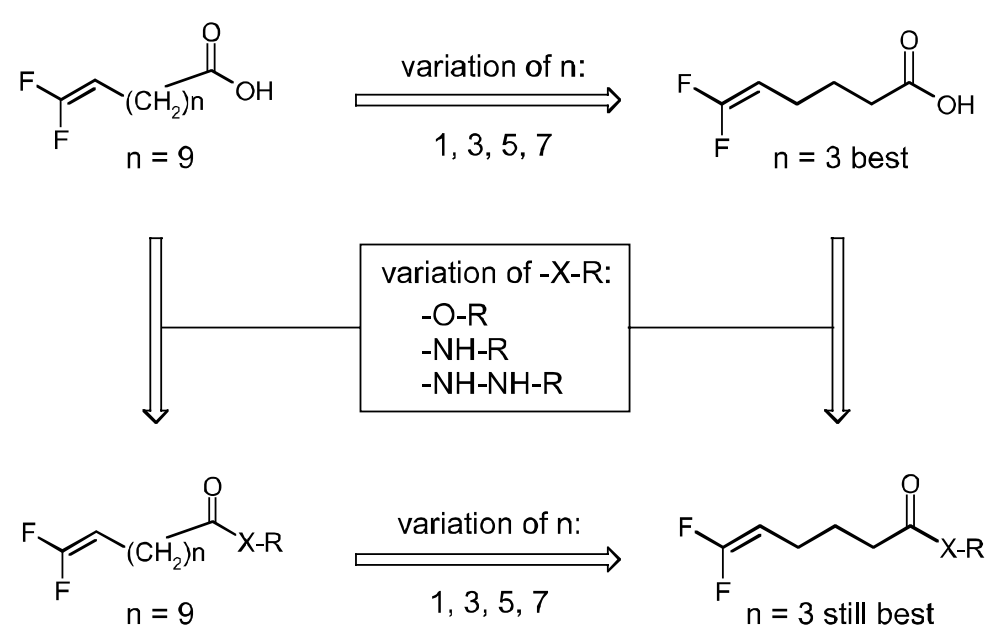

Fig. 4. Second optimisation cycle. Combined variations of bridge and tail part.

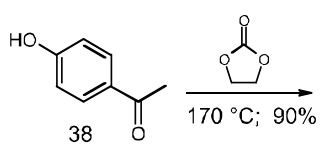<smiles>CC(=O)c1ccc(OCCO)cc1</smiles>
$\stackrel{\mathrm{MCPBA}, \mathrm{CH}_{2} \mathrm{Cl}_{2}}{\text { then } \mathrm{KOH}, \mathrm{MeOH}}$
$\underset{85 \%}{\longrightarrow}$<smiles>OCCOc1ccc(O)cc1</smiles>

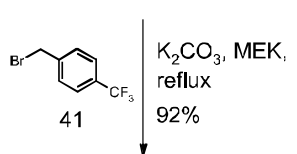<smiles>O=C(Cl)CCC=C(F)CCCC(=O)OCCOc1ccc(OCc2ccc(C(F)(F)F)cc2)cc1</smiles><smiles>OCCOc1ccc(OCc2ccc(C(F)(F)F)cc2)cc1</smiles> 
Table 4. Biological activity of selected compounds from the second optimisation cycle

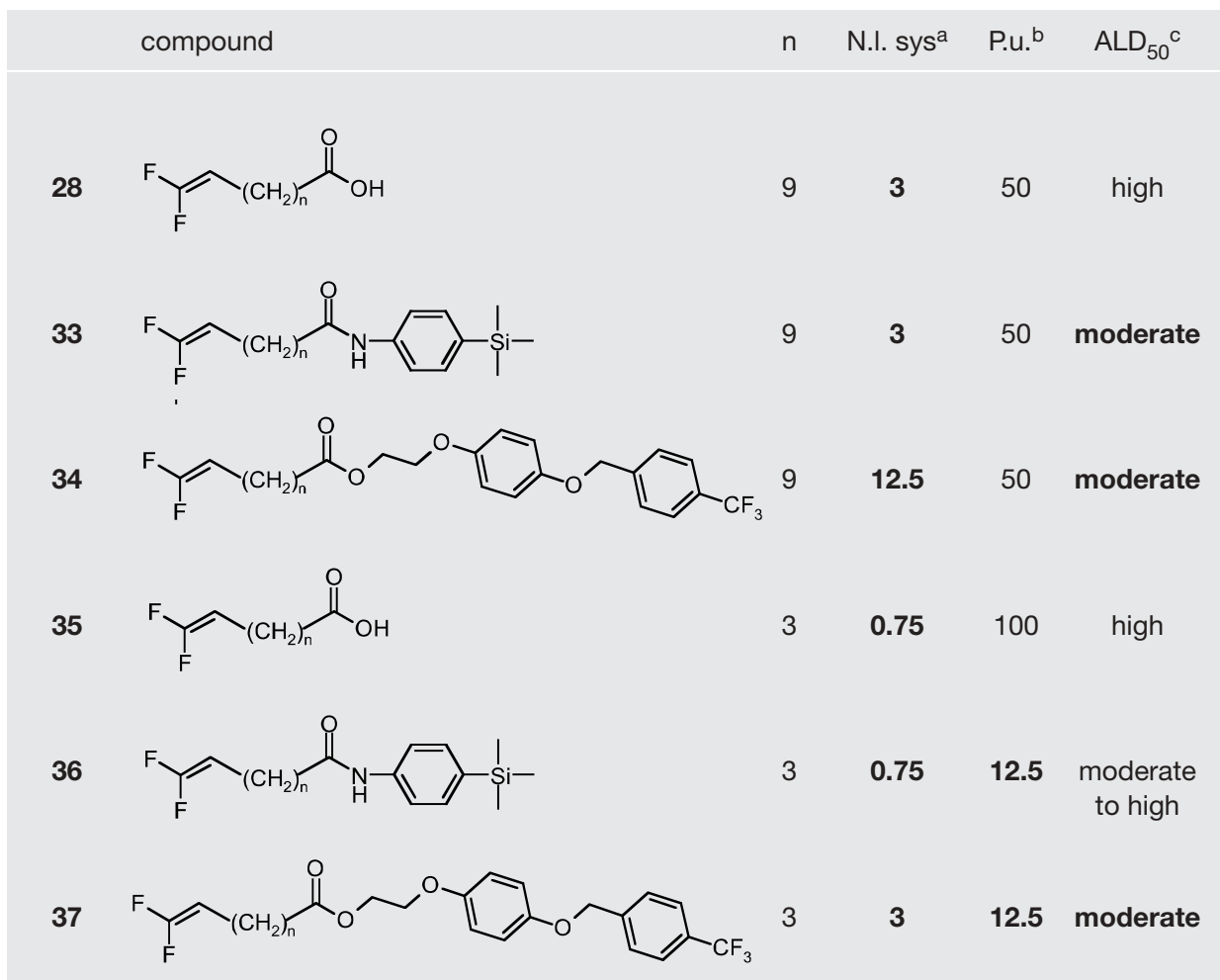

Biological activities in the table are given as $\mathrm{EC}_{80}$ in ppm. aNilaparvata lugens systemic activity, ${ }^{\mathrm{b}}$ Panonychus ulmi activity, ${ }^{\mathrm{C}}$ acute oral toxicity in the rat.
We reasoned, that elimination of fluoride from 6,6,6-trifluorohexanoic acid (51) could potentially be an extremely short route to our target. Indeed, with potassium tert-butoxide as a base this reaction proceeded in good yield (Scheme 7). 6,6,6-Trifluoro-hexanoic acid (51) was obtained from hexanedioic acid (49) after treatment with $\mathrm{SF}_{4}$ in HF. Similarly, the ethyl ester $\mathbf{5 2}$ was obtained from monoester 50. These fluorination reactions were developed in collaboration with the former Ciba Geigy catalysis group (now part of Solvias AG). However, despite valiant efforts to optimise, the yields of 6,6,6-trifluoro-hexanoic acid (51) or of its ester $\mathbf{5 2}$ never exceeded $50 \%$.

Therefore, we turned to the use of fluorinated building blocks. Radical addition of $\mathrm{CF}_{2} \mathrm{Cl}-\mathrm{CCl}_{3}$ to but-3-enoic acid (53) (Scheme 8) proceeded in useful yield. The product 54 was esterified with methanol. From the resulting ester 55, all chlorine atoms could be removed by an elimination - hydrogenation - elimination sequence. The first elimination step with triethylamine gave $\mathbf{5 6}$ in good yield. In the following step, both double bonds in $\mathbf{5 6}$ were hydrogenated and the chlorine atom $\mathrm{Cl}-\mathrm{C}(5)$ removed to give 57. Finally, a second elimination with DBU as a base, followed by
Scheme 6. Synthesis of 6,6-difluorohex-5-enoic acid (35) by a difluoro ylide approach

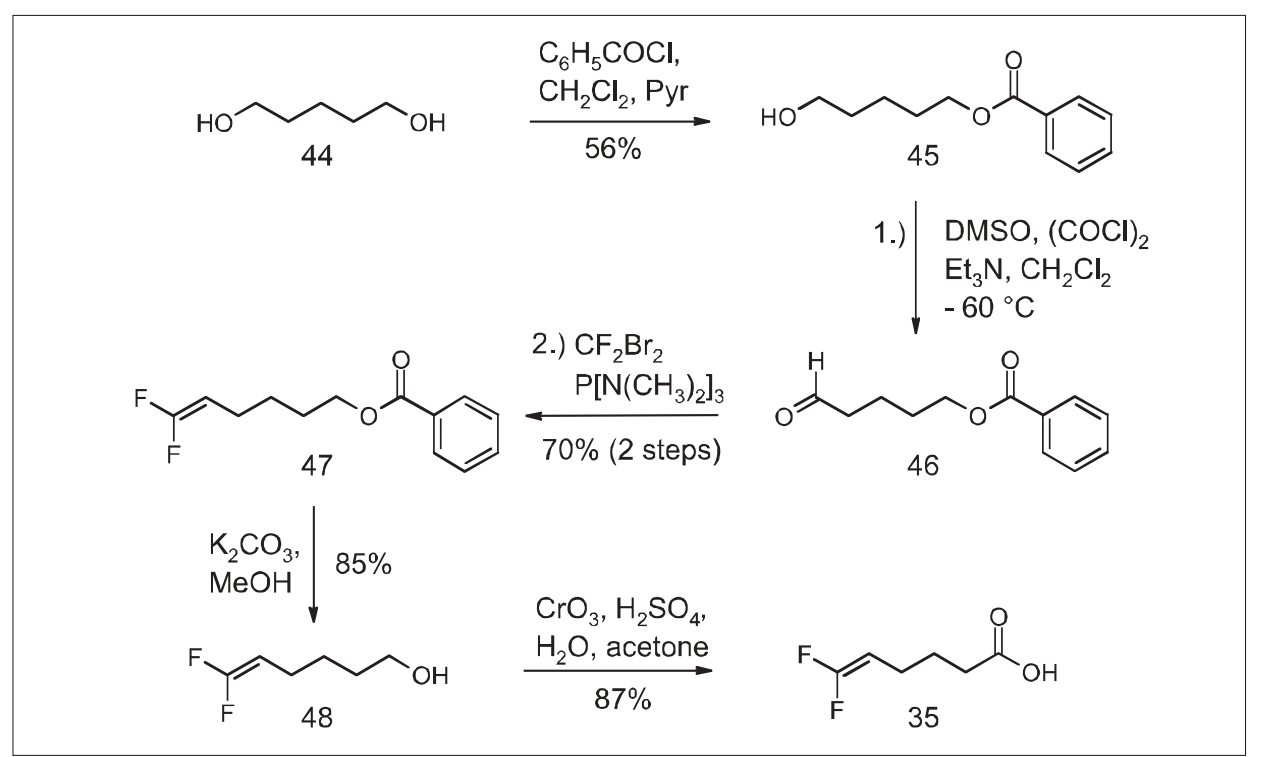

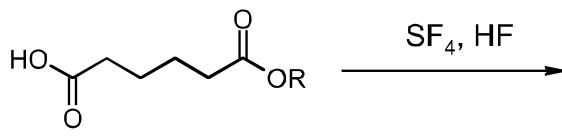

$49 \quad(\mathrm{R}=\mathrm{H})$

$50 \quad(\mathrm{R}=\mathrm{Et})$<smiles>O=C(O)CCCCC(F)(F)F</smiles>

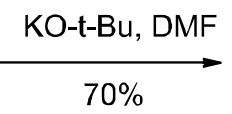

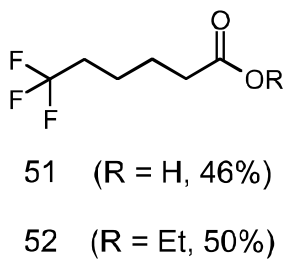

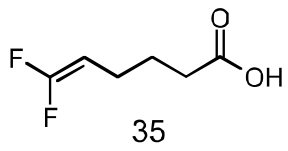


<smiles>C=CCC(=O)O</smiles>

53<smiles>COC(=O)/C=C/C=C(\Cl)C(F)(F)Cl</smiles>

56

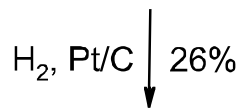<smiles>COC(=O)CCCCC(F)(F)Cl</smiles>

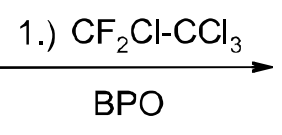<smiles>O=C(O)CC(Cl)CC(Cl)(Cl)C(F)(F)Cl</smiles>

2.) $\mathrm{MeOH}$ $\mathrm{H}^{+}$

$56 \%$ 2 steps<smiles>CC[18OH]</smiles>

1.) $\mathrm{DBU}, 75 \%$

2.) $\mathrm{K}_{2} \mathrm{CO}_{3}, \mathrm{MeOH}$ $92 \%$<smiles>COC(=O)CC(Cl)CC(Cl)(Cl)C(F)(F)Cl</smiles>

55
Scheme 8. Synthesis of 6,6-difluorohex-5-enoic acid (35) from $\mathrm{CF}_{2} \mathrm{Cl}-\mathrm{CCl}_{3}$ and but-3-enoic acid (53).

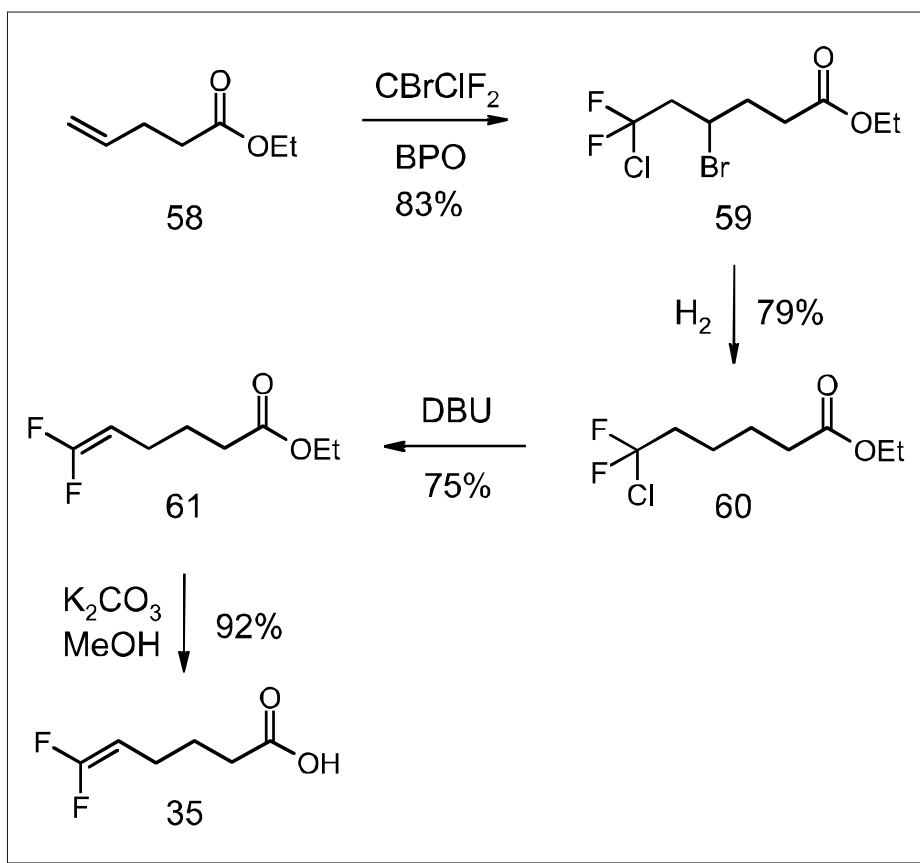

Scheme 9. Synthesis of 6,6-difluorohex-5-enoic acid (35) from $\mathrm{CBrClF}_{2}$ and pent-4-enoic acid ethyl ester (58)

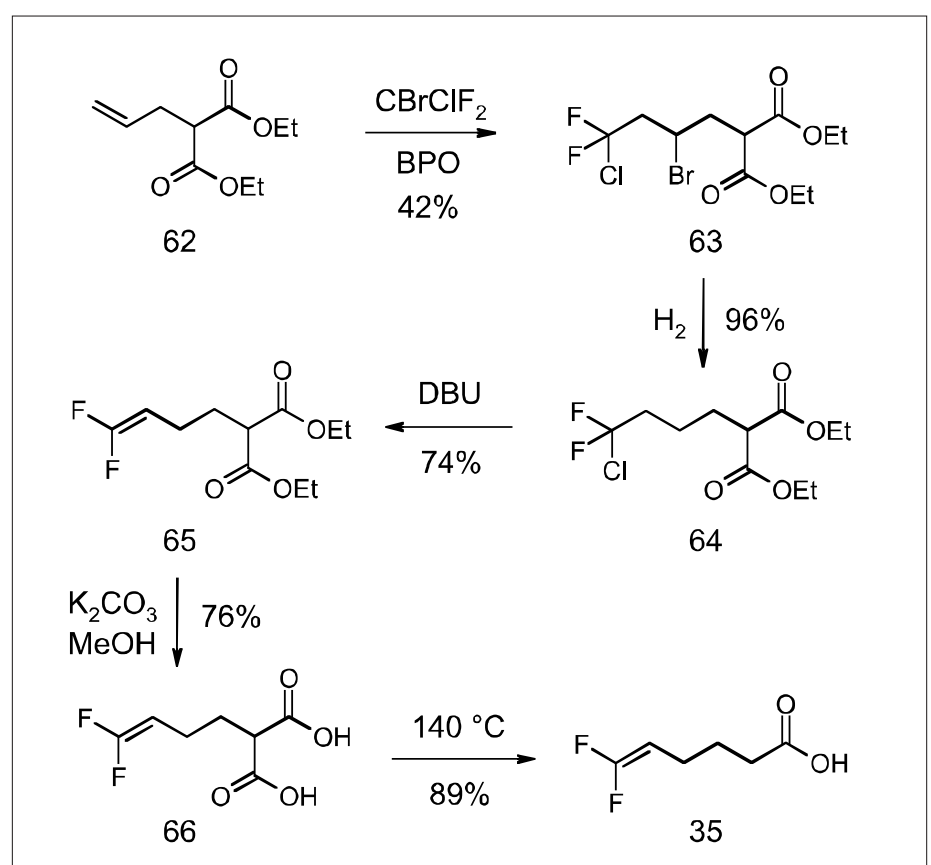

Scheme 10. Synthesis of 6,6-difluorohex-5-enoic acid (35) from $\mathrm{CBrClF}_{2}$ and 2-allyl-malonic acid diethyl ester (62) saponification of the ester group gave acid 35. Although the yield of the hydrogenation step was low $(26 \%)$, we did not further optimise it, because the following route turned out more promising.

Radical addition of $\mathrm{CBrClF}_{2}$ to pent-4enoic acid ethyl ester (58) proceeded very efficiently (Scheme 9). Bromide was removed from the product $\mathbf{5 9}$ by catalytic hydrogenation to give $\mathbf{6 0}$, chloride eliminated by treatment with base, and the ester $\mathbf{6 1}$ hydrolysed to give 35. All four steps of this sequence proceeded with good yield. This synthetic route is most efficient, and we used it successfully for the synthesis of several hundred grams of 6,6-difluorohex-5enoic acid (35).

In a variation of the above, we also investigated the radical addition of $\mathrm{CBrClF}_{2}$ to 2-allyl-malonic acid diethyl ester (62) (Scheme 10), which is a potentially cheaper starting material as compared with pent4-enoic acid ethyl ester (58). However, the yield of the addition product $\mathbf{6 3}$ remained unsatisfactory, $42 \%$ in the best case. In contrast, the following steps proceeded quite efficiently. They involved removal of bromine by catalytic hydrogenation to give 64, elimination of chloride from 64 with DBU as a base, hydrolysis of both ester groups of $\mathbf{6 5}$ and decarboxylation of diacid 66 at $140{ }^{\circ} \mathrm{C}$ to give 35 .

In summary, we have identified five synthetic routes for 6,6-difluorohex-5enoic acid (35). The best synthesis follows a fluorinated building block approach, and it involves the radical addition of $\mathrm{CBrClF}_{2}$ to pent-4-enoic acid ethyl ester. This route was used for scale-up to a several hundred 
gram scale. It allowed us to provide sufficient material for field trials.

\section{Conclusion}

The insecticidal lead 1,1-difluoro-1-dodecene (1) was optimised. In a first optimisation cycle, broad activity against insect pests and mites was discovered. The specific role of fluorine in this class of insecticides is its contribution to the essential $\mathrm{gem}$ difluorovinyl pharmacophor, as gem-difluorovinyl derivatives interfere with the $\beta$-oxidation of fatty acids in insect mitochondria.

In a second optimisation cycle, CGA 304'111 (37) was discovered. It showed excellent performance in field trials against a wide range of pests. In addition, 37 also showed a more favourable toxicological profile than earlier derivatives.

A practical synthesis was identified, which allowed the preparation of larger samples (several hundred gram scale).

\section{Acknowledgement}

We wish to thank Alfred Rindlisbacher (Syngenta AG) for the assessment of biological activity and Franz Ruder (former Ciba-Geigy AG) for biochemical studies. For synthetic collaborations we thank Tibor Gögh and Marcela Göghova from Synkola, Hermann Rempfler, Henry Szczepansky and Rudolf Waditschatka from Syngenta AG, and Heinz Steiner from Solvias AG.

Received: December 19, 2003

[1] K. Naumann, B. Becker, W. Behrenz, B. Homeyer, W. Stendel (Bayer A.-G.), Ger. Offen., DE 3618115, 1987.

[2] F. Ruder (Ciba-Geigy AG), personal communication.

[3] S. Hayashi, T. Nakai, N. Ishikawa, D.J. Burton, D.G. Naae, H.S. Kesling, Chem. Lett. 1979, 983.

[4] W.J. Middleton, J. Org. Chem. 1975, 40, (5), 574.

[5] M. Schlosser, B. Schaub, Chimia 1982, 36 (10), 396.

[6] a) R. Appel, Angew. Chem. 1975, 87, 863; b) R. Appel, P. Knoll, W. Michel, W. Morbach, H.D. Wihler, H. Veltmann, Chem. Ber. 1976, 109, 58.

[7] E.J. Corey, P.L. Fuchs, Tetrahedron Letters 1972, 13 (36), 3769.

[8] M. Suda, Tetrahedron Letters 1980, 21 (26), 2555.

[9] a) J.C. Brahms, W.P. Dailey, J. Org. Chem. 1991, 56 (2), 900; b) D.J. Burton, A.L. Anderson, R. Takei, H.F. Koch, T.L. Shih, J. Fluorine Chem. 1980, 16 (3), 229.

[10] a) I.L. Knunyants, V.R. Polishchuck, Usp. Khim. 1975, 44 696; b) V.R. Polishchuck, E.I. Mysov, I.V. Stankevich, A.L. Chistakov, K.A. Potechin, Y.T. Struchkov, J. Fluorine Chem. 1993, 65, 233; c) C.G. Krespan, V.A. Petrov, Chem. Rev. 1996, 96, 3269.

[11] J.T. Kendall, D.M. Lemal, J. Fluorine Chem. 1997, 83 (2), 171.
[12] D. Baumert, H. Franke, D. Giles, G. Hoemberger, A. Koehn, N. Skuballa, P. Wegner, Special Publication - Royal Society of Chemistry, 1994, 147 (Advances in the Chemistry of Insect Control III), 171.

[13] P. Maienfisch, T. Pitterna, M. Böger, Eur. Pat. Appl., EP 577555, 1994.

[14] P. Maienfisch, M. Böger, T. Pitterna, H. Szczepansky, Eur. Pat. Appl., EP 661289, 1995. 